\title{
Social Movement Structures in Relation to Goals and Forms of Action: An exploratory model
}

\author{
Jurgen Willems \& Marc Jegers \\ Vrije Universiteit Brussel, Belgium
}

\begin{abstract}
This article describes a theoretical taxonomy of the structural features of social movements. We begin by using two classification criteria to analyze the types of relations that characterize the structure of social movements. From there, we look at how differences in structure relate to different goals and forms of action. We then derive a four-fold classification system based on formalization and hierarchy of relationships. For each classification we provide case descriptions of social movements (or parts thereof) using literature on how different movement structures support different types of goals and forms of action. Furthermore, we discuss the dynamics of social movements (or parts thereof) and how their classification may evolve. By doing so, we illustrate how changes in structure, goals, and forms of action mutually influence each other.
\end{abstract}

\section{RÉSUMÉ}

Cet article dresse une taxonomie théorique des caractéristiques structurelles des mouvements sociaux. Nous utilisons d'abord deux critères de classification pour analyser les types de relation propres à la structure des mouvements sociaux. Par la suite, nous observons comment des différences de structure coïncident avec des buts et des formes d'action différents. Nous développons ensuite un système de classification quadruple fondé sur la formalisation et l'hiérarchisation des relations. Pour chacune des classifications, nous fournissons des descriptions de cas de mouvements sociaux (ou de parties de ceux-ci) en recourant à des écrits sur la manière dont des structures de mouvement différentes entraînent des buts et des formes d'action différents. En outre, nous discutons des dynamiques des mouvements sociaux (ou de parties de ceux-ci) et comment leur classification pourrait évoluer. Par ce moyen, nous illustrons comment des changements de structure, de but et de forme d'action s'influencent réciproquement.

Keywords / Mots clés : Social Movements; Goals; Tactics; Structure; Coordination; Strategy / Mouvements sociaux; Buts; Tactiques; Structure; Coordination; Stratégie 
Willems and Jegers (2012)

\section{INTRODUCTION}

In this article we explore and theorize about the mutually reinforcing relationship between the structural characteristics of social movements, on the one hand, and goals and forms of action, on the other. In particular, we focus our analysis on how differences in structural features of social movements serve different types of goals and forms of action. We present a taxonomy based on a characterization of the relationships that exist between actors within social movements. With this taxonomy we aim to provide a framework to explore an important research gap in the contemporary nonprofit and social economy literature (see next section). For the development of our taxonomy, we combine a social movement perspective with an organizational structure perspective. This enables us to 1) pinpoint the particularities of the research gap that we deal with, and 2) build upon important earlier contributions.

\section{RESEARCH GAP}

Most often in the organizational structure literature, at least with respect to formal for-profit organizations, structure and forms of action are considered simply a means to an end in so far as reaching organization specific goals (Child \& Francis, 1976; Kukalis, 1991). However, organizations with a social goal (often referred to as nonprofit, social-profit, or civil society organizations) can seldom be seen as stand-alone entities, as the achievement of their organizational missions and goals can strongly depend on the achievements of other actors in the field (DiMaggio, 2001). The conceptual grouping of various organizations, individuals, and institutions based on a common social goal and/or mission is referred to as a social movement (Coleman, 1988; Kriesi, 1996; Zald \& Ash, 1966). Within the context of these social movements we argue that structure, forms of action, and types of goals are mutually interacting. Decisions regarding structure, goals, and forms of action are made separately by different entities at different levels within a movement (Hensmans, 2003). Multiple coordination mechanisms, in contrast to hierarchically centered coordination, are at the origin of the typifying collective identification and collective action of social movements, as they empower different actors to identify with a common goal and to adjust their strategies to achieve their part of it (Bakuniak \& Nowak, 1987; Coleman, 1988; Simon, Loewy, Stürmer, Weber, Freytag, Habig, Kampmeier \& Spahlinger, 1998). As a result, within social movements changing structures, forms of action, and types of goals mutually influence each other in a dynamic, on-going process. In this article we apply our proposed taxonomy to explore this process in further detail.

Despite the fact that the organizational structure of social movements has already been extensively explored in the literature (Jenkins \& Eckert, 1986; Kriesi, 1996; McCarthy \& Wolfson, 1996; McCarthy \& Zald, 1977b), the focus in such contributions tends to be on the structure of their formalized components and, in particular, Social Movement Organizations (SMOs). SMOs are the formal nonprofit, social-profit, and/or civil society organizations that share interdependent missions and visions,and are associated with broader social movements. When looking at the institutionalization of movements, SMOs have been studied for the central role they play in the evolution of social movements (Burstein \& Linton, 2002; Taylor \& Doerfel, 2011; Zald \& Ash, 1966). However, when focusing only or too strongly on SMOs, we are confronted with two major inadequacies: one is the issue of dynamism in social movements and the other is with regard to the heterogeneity of various actors in social movements.

SMOs emerge from informal connections between individuals and other organizations, and over time, these connections begin to formalize. From a dynamic perspective, given that SMOs are typically analyzed once they are formalized and already have a particular form of organizational structure, there is the risk that we will neglect important informal structures. In addition, with a too strict focus on SMOs as units of analysis, the overall underlying structure of the social movement, within which SMOs are only a part, might be ignored. For example, when social movements evolve over time, some goals and forms of actions might become more prominent than others (Armstrong, 2005; Johnson, 2008; McAdam \& Scott, 2005). In parallel, the overall structure of the social movement 
can change substantially, both formally and informally (Anheier, 2003; McCarthy \& Zald, 1977a; Thorthon, 2002). As a result, a too strict focus on SMOs for our analysis would neglect the informal dynamics at the origin of SMOs and the changing goals, strategies, and relations of social movement actors.

The second inadequacy is that the heterogeneity of actors involved in a social movement (e.g., individuals, groups of organizations, alliances, or even whole segments of society) is overlooked when SMOs, rather than social movements as such, are the units of analysis. In addition, the relationships and partnerships that can exist between these actors are also not sufficiently addressed, despite their crucial role in the study of social movements (Snow, Zurcher \& Ekland-Olson, 1980).

For the development of our taxonomy we build on Tarrow's (1994) definition of social movement structure, in which he presents three main elements. The first element is "formal organization." This element is the most, and often only element of social movement structure studied, and pertains to the structure and the role of formal organizations within social movements. The second element is the "organization of collective action," and concerns the characteristics of the relationships between entities involved in social movements (Tarrow, 1994, describes these entities as the "antagonists" of social movements). The third element, "mobilizing structures," relates to the coordinating mechanisms that adjust the goals and forms of action of the different entities within a social movement. In the taxonomy proposed in this article, we focus on the second and third elements. We start by classifying types of relations that can exist between entities (relating to Tarrow's second element) in a social movement, and use case studies to describe how through mobilizing structures (the third element), certain types of goals can be served and what forms of actions are supported.

By use of case studies from the literature, we exemplify certain structural aspects of social movements and derive the goals and forms of actions supported by these structures. We choose case studies from different social movements in order to build our framework on general tendencies rather than case-specific observations (Benford, 1997). We begin by describing the cases at one particular moment in their history, and then combine these descriptions with a discussion on how structure, goals, and forms of action can evolve over time. Indeed, as we stress in this article, we cannot ignore the dynamic nature of social movements (Benford, 1997; Benford \& Snow, 2000).

\section{MODEL CLASSIFICATION VARIABLE: MOVEMENT STRUCTURE}

Similar to Kriesi (1996), we propose a four-fold classification system. However, instead of classifying SMOs based on their goals within the social movement, we classify them based on two relational characteristics of social movement structure. We define the movement structure of a social movement (or a part thereof), as the system of relations that exist between all entities involved in a given social movement (again, or part thereof). Based on this system of relations and their characteristics, entities within the social movement are defined in relation to one other. Expressing these relationships clarifies the particular role of the different entities within a social movement. In our model, we do not focus on the types of entities that are related to each other, but rather on the different types of relations that can exist between them. Entities can be individuals, organizations, groups of people, or even whole segments of society. The relationships, on which our classification system is based,can be between entities of the same type (e.g., friendship relations between individuals, or partnerships between two organization), or between entities of different types (e.g., a person being a member of an organization). As a result, and in contrast to many other entity-based classifications of social movements, we base our classification on the relational characteristics within movements. In this article we look at two generic characteristics of relations within the movement structure of a social movement: 1) the extent to which relations are either formal or informal, and 2) the extent to which the relations are hierarchical or lateral. We deal with both characteristics separately in the following two subsections. 


\section{Formal versus informal relations}

The first continuous dimensional characteristic concerns the relative level of formality of relations in social movement structure. On one end of the continuum we consider highly formalized relationships, and on the other, highly informal relationships. Defining characteristics and examples of formal and informal relations are given in Table 1.

\section{Table 1: Defining characteristics and examples of informal and formal relationships}

\begin{tabular}{|c|c|}
\hline Informal relationship & Formal relationship \\
\hline $\begin{array}{l}\text { Characteristics } \\
\text { - Implicit and unwritten } \\
\text { - } \\
\text { Flexible (no particular rules exist to form such } \\
\text { relationship; relationships are easy to break) } \\
\text { - } \text { hantent of relationship is based on culture, } \\
\text { - Trust based beliefs }\end{array}$ & $\begin{array}{l}\text { Characteristics } \\
\text { - Externalized and/or recorded (contracts, } \\
\text { agreements, partnerships, alliances, etc.) } \\
\text { - Rigid (actions of both parties are determined. } \\
\text { Parties know what is to be expected): Reduces } \\
\text { uncertainty in the future for the partners in the } \\
\text { relationship } \\
\text { - Content of relationship is based on a legal } \\
\text { system and/or a set of widely accepted rules } \\
\text { (relates to legal legitimacy) }\end{array}$ \\
\hline $\begin{array}{l}\text { Examples } \\
\text { - Friendship relation between two individuals } \\
\text { - One-time financial donation of individual to a } \\
\text { SMO } \\
\text { - Spontaneous participation in demonstration } \\
\text {-Gentlemen's" agreement and/or cartel } \\
\text { between organizations }\end{array}$ & $\begin{array}{l}\text { Examples } \\
\text { - Formal marriage between two individuals } \\
\text { - Legal contract between individuals and/or } \\
\text { organizations. } \\
\text { - Formal membership of individual to an } \\
\text { organization } \\
\text { - Strategic alliance between organizations } \\
\text { Employment contract between individual and } \\
\text { organization }\end{array}$ \\
\hline
\end{tabular}

Relations within a movement's structure can be strongly formalized based on legal agreements, contracts, firm and corporation configurations, and/or partnerships. On the other end of the continuum, relations can be very informal, based on individual contacts, unwritten agreements, and/or cultural customs and habits. Both types of relations, or variations in between, serve organizational structures in a particular way. The formalization of relations can be a way of reducing uncertainty as it relates to the behaviour of the other actor in the relationship. Nevertheless, there are certain costs associated with initiating and maintaining such relationships (Coase, 1937; Williamson, 1991). Furthermore, formalized relations can create a sense of legitimacy from the perspective of actors that are not involved in the relationship (Suchman, 1995) and are more appropriate when concerning the exchange of private and complex knowledge (Hansen, 1999; Uzzi \& Lancaster, 2003).

In contrast to formal relationships, informal relationships are at the base of more flexible structures but are more contingent on external factors. Nevertheless, due to low initiation and maintenance costs, they can exist in large quantities (Granovetter, 1973) and can serve for quick exchanges of public and basic knowledge (Hansen, 1999; Uzzi \& Lancaster, 2003). Both of these aspects are crucial for creating collective identity and initiating collective 
action. In Figure 1, we represent formal relationships by use of full lines (quadrants I and II), while informal relationships are represented by dotted lines (quadrants III and IV).

\section{Hierarchical versus lateral relations}

For the second continuous dimension of our classification system we contrast hierarchical relations and lateral relations. This distinction reflects the position that actors have with respect to one other. In a hierarchical relation one actor has power and/or authority over the other, either formally or informally. In a hierarchical structure, a limited group of entities controls the majority of other entities involved. In lateral relations, actors have equal positions. Table 2 summarizes the defining characteristics and examples of hierarchical and lateral relationships.

\section{Table 2: Defining characteristics and examples of hierarchical and lateral relationships}

\begin{tabular}{|c|c|}
\hline Hierarchical relationships & Lateral relationships \\
\hline $\begin{array}{l}\text { Characteristics } \\
\text { - One actor has formal or informal } \\
\text { - } \quad \text { One actor has a representative and/or } \\
\text { decisive role over the other } \\
\text { - Power of one actor towards another is related } \\
\text { to the ability and/or willingness to keep or } \\
\text { share information with another actor }\end{array}$ & $\begin{array}{l}\text { Characteristics } \\
\text { - } \text { Actors have equal power status within } \\
\text { relationship } \\
\text { - } \text { Reciprocity } \\
\text { - } \quad \text { Relation is based on mutual exchange of } \\
\text { information and knowledge }\end{array}$ \\
\hline $\begin{array}{l}\text { Examples } \\
\text { Formal } \\
\text { - Manager versus employee in formal } \\
\text { organization } \\
\text { - Elected representatives within a union } \\
\text { - Formal membership of SMOs in an umbrella } \\
\text { organization } \\
\text { Informal } \\
\text { - An individual personalizing an ideology } \\
\text { - "Think tanks" issuing pamphlets, manifests, etc. }\end{array}$ & 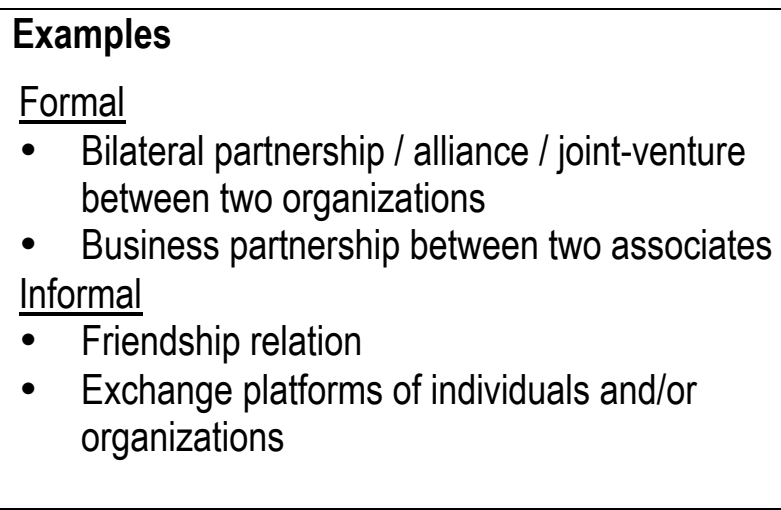 \\
\hline
\end{tabular}

A hierarchical relationship between two actors implies that one actor is in a position of subordination, while the other is in a position of coordination and/or power (Leflaive, 1996). Within formal organizations, hierarchical relationships are inherent to the division of tasks and are dependent on the different environments in which an organization is active (Lawrence \& Lorsch, 1967; Williamson; 1967). However, when the set of actors is more heterogeneous and/or less formalized within a single organization, hierarchical relationships result from the presences of more centralized actors in a network structure (Galaskiewicz, 1985; Roelofs, 2009), In particular, these central actors can play a major brokerage role in the diffusion of ideas, information, and resources, creating a position of power and authority (Burt, 2004; Obstfeld, 2005).

In contrast to hierarchical relationships, lateral relationships imply the relative equal positioning of actors. In formalized structures, lateral integration between equal level subsystems can improve the overall effectiveness with 
which an organization can reach its goals, as subsystems can better align their actions and strategies towards each other (Lawrence \& Lorsch, 1967; Galbraith, 1971). Across boundaries of single organizations, strategic alliances or partnerships can exemplify and explain the rationale of lateral relationships between organizations (Arya \& Lin, 2007; Das \& Teng, 2000; Provan \& Milward, 2002; Selsky \& Parker, 2005; Shumate, Fulk \& Monge, 2006). Furthermore, at the individual level lateral relations exist in informal settings (such as among family, friends, or in neighbourhoods) and in formal settings (such as relationships based on contracts and codes of conduct).

For our taxonomy of social movements we distinguish between a centralized structure, encompassing mainly hierarchical relations, and a clustered structure, encompassing mainly lateral relations. In Figure 1, quadrants I and IV give a representation of centralized structures, while quadrants II and III give a representation of clustered structures.

\section{Figure 1: Classification of movement structure based on relationship types}

Formal Structure

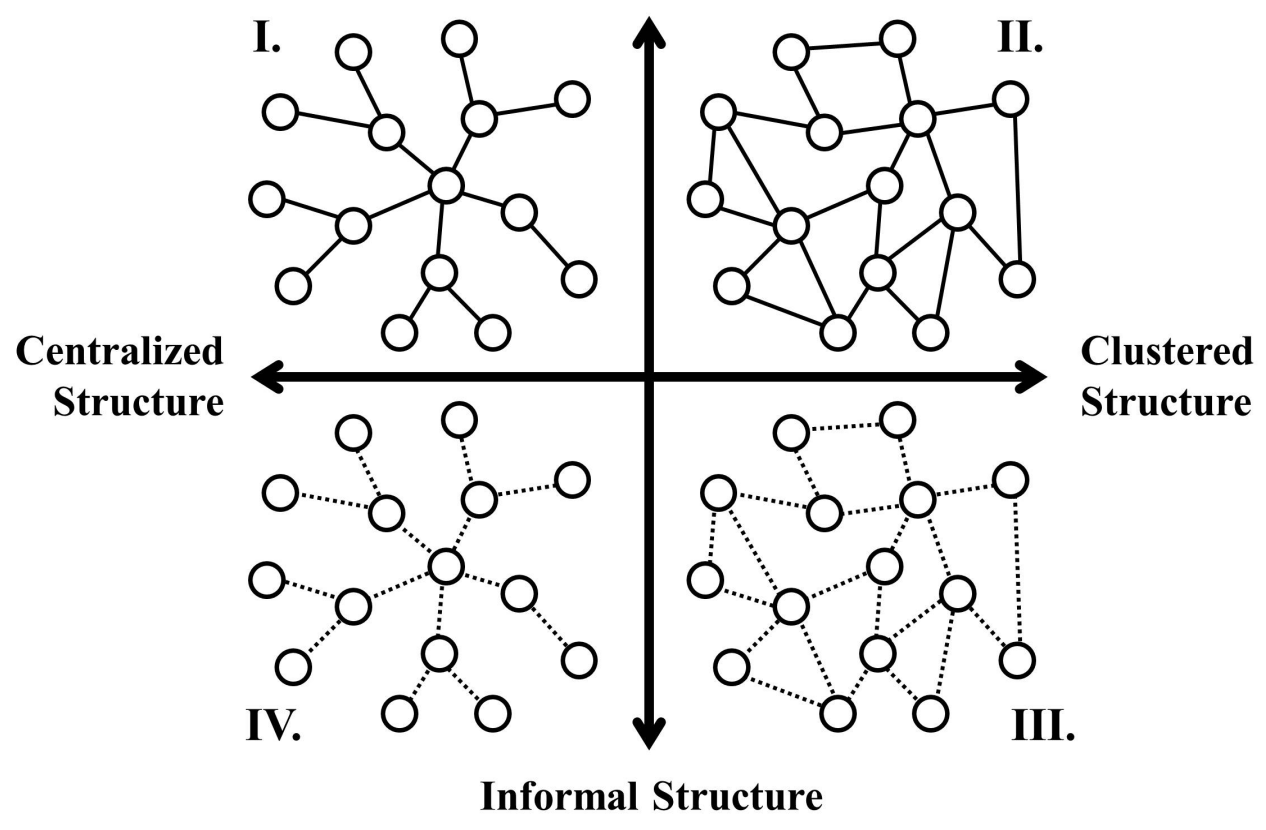

\section{GOALS AND FORMS OF ACTION IN SOCIAL MOVEMENTS}

Based on the two dimensions introduced above, we can distinguish between four quadrants. In the remainder of this section we will discuss each quadrant by use of literature-based case study analysis. However, before doing so we stress two important things. First, as mentioned earlier, the dimensions introduced should be understood as a description of two opposite situations within a continuum of many potential movement structures alternatives. By discussing each quadrant of the four-fold classification separately, we can draw theoretical findings from general tendencies. Second, it is not our aim to classify separate social movements forever within one of the four quadrants. Social movements are dynamic and their movement structures, goals, and forms of action might differ strongly for different sub-currents and for different moments in time. Within the cases we look at specific situations and deduce within them, a relation between organizational structures, goals, and forms of action. In addition, we mention the potential evolution of social movements between quadrants in order to incorporate the dynamics described in the 
case studies (Benford, 1997; Benford \& Snow, 2000). The four subsequent sections discuss the four quadrants as numbered in Figure 1, respectively.

\section{Formal centralized structures}

The literature provides many examples of social movements characterized by formal and centralized structures. These cases most often deal with social movements that have gradually institutionalized over time. At a certain phase in their evolution, the underlying structure of a given social movement is typified by a large set of actors, including many individuals grouped in different organizations that in turn are grouped and centralized under umbrella organizations, political platforms, and/or political formations.

For these cases, the strong degree of formalization and the many hierarchical levels indicate broad support and/or a large built-up capacity. Such evolutionary processes often require significant periods of time. Through formalization and centralization, a movement's structure can support and sustain achievements reached in the past. Zald and Ash (1966) state that the formation of coalitions and mergers of different actors in a social movement towards a centralized structure creates a broader resource base than when a single indivisible goal or position is at stake. The most common examples given of centralized and formalized structures are contemporary labour movements.

Buhlungu (2008) describes the case of the evolution of a union (Congress of South African Trade Unions [COSATU]), its structure and forms of action in South Africa in the years following the first democratic elections in 1994. The author describes how during the seventies and eighties this union, as part of the broader South African labour movement, built up a large base of supporters through its activities. Currently the movement aims to sustain rights for labour forces through strong centralized initiatives such as "collective bargaining, ... the tripartite alliance of ANC, COSATU and the SACP, lobbying of parliament and participation in several ad-hoc committees set-up by government" (Buhlungu, 2008, p. 41). Importantly, Buhlungu remarks that COSATU's organizational structure has been under pressure from external forces in South-African society in the last decade, such as globalization and the strong growth of democratization. Despite the fact that some contributions in the literature often indirectly assume institutionalization of a social movement as a final point of the evolution, Buhlungu (2008) argues that even these structures might be under pressure. Due to the above-mentioned external changes, the movement's structures might become subject to either marginalization or revitalization; revitalization being a process of change in response to the organization becoming too bureaucratic (formalized) and oligarchic (centralized).

Voss and Sherman (2000) further elaborate on this process in their analysis of the revitalization of American unions and investigate the "iron law of oligarchy," which states that through the institutionalization of social movements the goal of SMOs becomes maintaining the organization in itself (as a final stage in the social movement evolution). In contrast to this "iron law" that explains social movement evolution predominantly based on internal factors, Voss and Sherman (2000) stress the combination of internal and external factors that are at the base of the revitalization of the labour movement. As such, they argue that maintaining the organization in itself is not the final step of a SMO. They identify as important drivers for revitalization of SMOs, (1) internal crises that might result from too much conservatism and bureaucracy, (2) the outside experience of new leaders, and (3) the intervention of higherlevel international union organizations. When movements are undergoing revitalization, their focus shifts to the maintenance of earlier achievements and to their incremental improvement, albeit through new and innovative tactics. These new tactics are brought in by new leaders and are often applied simultaneously in "comprehensive campaigns" that aim to react to contemporary societal changes (Voss and Sherman, 2000) As a result, rather than maintaining the organization in itself, the organization's strategy and goal can be described as "a gradual adoption 
of a range of tactics and a strategic way of thinking that is focused on challenging the employer's advantage and preventing employers from conducting "business as usual"' (Voss \& Sherman, 2000, p. 312).

In general, formalized and centralized structures group a large base of actors in different hierarchical and formally coordinated layers. This enables a social movement to build on a broad resource base and/or a big democratic-like representation of the actors involved in the movement. The degree of centralization (resulting in a singular voice for the movement) and the level of formalization (reducing uncertainty but also flexibility), support the long-term sustainability of a movement and incremental enhancements on past achievements. Forms of action build upon the broad resource capacity and/or the representation of the many actors involved. The presence of increasingly formalized structures and a limited number of voices speaking for the movement also facilitates (political) bargaining through a variety of methods (or campaigns) that can be gradually intensified over time (e.g., lobbying, negotiation, mobilization, marches, strikes, etc.).

\section{Formal clustered structures}

The description of the American environmental movement given by Johnson (2008) and Hoffman (2009) provides an interesting example of a formal and clustered structure. Although Hoffman's example does not focus on the evolutionary aspects of the environmental movement as such, he argues that the different currents within the broader environmental movement during the last decades have led to the scattering of many different types of organizations each with its own specific goals and tactics. This allows some organizations to focus on particular aspects of the overall environmental cause, while others deal with a wide variety or more broad environmental issues. At the same time, organizations can employ different tactics, for example, either collaborating with the corporate world (e.g., mobilization, lobbying, negotiation) or opposing the corporate world (e.g., protest or sabotage).

The focal point of Hoffman's work, however, is not so much the particular goals and forms of action of independent organizations, but rather the role of different types of organizations within the overall environmental cause. By mapping and classifying environmental organizations based on the formal relations that they have with for-profit organizations and their position within the overall network, Hoffman (2009) distinguishes between different roles that organizations take in the overall environmental cause. As a result, the formal and clustered movement structure brings together different actors, each with their own specific goals and tactics, but who ultimately contribute towards the overall and broader environmental cause.

In contrast to Hoffman, Johnson (2008) focuses on the dynamics of the environmental social movement. He investigates how growth of the environmental sector and the diversification of formalized environmental SMOs impact legislation changes in the United States. Due to the large amount of diversification, which he argues is the result of the formalization and professionalization of the sector, actors can specialize on particular topics within the broader environmental cause. In addition to specialization, environmental activist organizations-driven by different ideologies, and depending on the collaborative and/or competitive nature of the relationships between themintentionally focus on certain tactics to differentiate themselves from other environmental organizations (Den Hond \& De Bakker, 2007).

The evolution of the environmental movement is similar to the crystallization of the gay and lesbian movement in the early seventies in San Francisco, as described by Armstrong (2005). At that time, the gay and lesbian movement was typified by a large set of formalized organizations, with each organization focusing on a particular aspect of gay and lesbian rights, but with sufficient linkages between them to work together on the general and broader cause. As cited by Armstrong (2005, p. 172): "The Formula: just enough structure and planning to have a 
sound foundation but not so much that action is impossible. Also, most new groups are limiting their activities to gay-oriented issues, rather than tackling all the world's ills at once." However, in subsequent years, the gay and lesbian movement seems to have centralized more and more until a consensus was built regarding the movement's goals. Armstrong (2005) reports the initiation of a nationwide political platform bringing together many organizations and initiatives scattered across the United States aimed at creating a unified strategy that is more politically oriented towards improving the living conditions for gays and lesbians. From this evolution, we can conclude that the social movement has shifted towards quadrant $\mathrm{I}$. This shift is demonstrated by the fact that from the seventies on, the movement's goals, and especially forms of action, are more focused on achieving incremental changes in society through political activism with the support of a large contingent of organizations and individuals.

In sum, a clustered and formal structure relates to movements with differentiated groups of actors with specialized goals and tactics (Ruef, 2000; Taylor, 2007). Nevertheless, through the alliances and partnerships that exist between actors, each of these goals contributes in some form to a general "cause." As a result, within the broad context of a general cause, complexity is inherently dealt with by specialization among the actors involved. Direct and formalized connections support bilateral collaboration in which strategies can be aligned and complex knowledge can be exchanged (Hansen, 1999; Uzzi \& Lancaster, 2003). In addition, indirect connections allow for the mediation of opposing strategies and forms of action (Eden \& Huxham, 2001), or, when a movement (or part thereof) shifts towards quadrant I, the creation of a centralized platform or umbrella organization can help sustain and improve common, but more general interests (Schneiberg, King \& Smith, 2008).

\section{Informal clustered structures}

At the origin of any type of organization lies the informal network of personal contacts that instigated initial collective action. In social movements we see that the early formation of informal networks helps build a sense of collective identity, even though there is an overall, but rather abstract goal (Bayat, 1997). McAdam and Scott (2005) give a detailed description of the Afro-American rights movement in the post-World War II era. During the period of its strongest growth, from the mid-fifties through the mid-sixties, the rights movement is typified as a set of many different actors and entities, including individuals, organizations, federal officials, and national media. The base of movement supporters grows substantially as a result of its broad and high-level goals, such as integration and voting rights, which were easy to identify with. In addition, spontaneous and large-scale actions took place, such as "sit-ins, mass marches and other forms of public protest and civil disobedience" (McAdam \& Scott; 2005, p. 33). In this phase, emerging "resource linkages" are important (McAdam \& Scott, 2005; McCarthy \& Zald, 1977a) as they enable the emergence of central actors who take a leading and innovative role in the informal network structure (Hargrave \& Van de Ven, 2006). From the early sixties on, due to the emergence of these leading central actors, referred to as the "Big Five" (McAdam and Scott, 2005; Rojas, 2006), one part of the movement switches to quadrant IV as central nodes become leading and/or more important in the networked structure (we will refer to this in next section). At the same time, another part of the movement progresses to quadrant II, formalizing the existing resource linkages and reducing uncertainty and enabling exchange of specialized and complex knowledge. The latter part of the movement shifts to a point where separate actors focus on specific goals and forms of action within the broader "cause," while supporting each other through alliances and partnerships.

The feminist movement, as described by Roth (2004) and Taylor (1989), has a structure that is even more informal than African American rights movement. Roth (2004) states that self-aware, autonomous feminist actors are a relative rarity in women's protest, and are in general more common to other movements or institutions. Clusters based on informal linkages exist across movement and institutional boundaries, and form the foundation of the overall collective identity of the feminist social movement (Taylor, 1989). Moreover, Roth (2004) classifies four different contextual situations in which the feminist movement might find itself, taking the "feminist-friendliness" and level of institutionalization of the environment of the movement into account. She explains how goals and actions 
diverge and specialize depending on the situation. Similar to the rights movement, such an informal and clustered structure supports mobilization towards an overall, yet (still) to be defined goal. The structure emerges rather spontaneously and relies heavily on the collective identity of the actors in the social movement. Nevertheless, it seems that the structure, in and of itself, is unstable, and naturally actors start formalizing their operations and/or begin to specialize in certain forms of actions, striving for more concrete goals and achievements (Taylor, 1989). Social movements (or their sub-currents) seem to switch over time from being unstable, informal, and clustered, to becoming more formalized and/or more centralized. This is due to the specialization of its actors and the emergence of dominant central nodes within the network structure.

In sum, informal and clustered structures grow from the emergence of a collective identity and the identification of common, but abstract goals. Forms of actions supported by the movement structure are spontaneous, flexible, and easy to identify with. The informal structures are identified as a major condition for creating and sustaining commitment to goals and forms of action (Robertson \& Tang, 1995; Snow et al., 1980). Examples of this type of forms of action are marches, sit-ins, petitions, demonstrations, and civil disobedience, as for these activities there is no need for formal or hierarchically coordinated mechanisms, large amounts of resources, and/or built-up capacity. However, when the movement endures, different actors might take more of a leading or central role, and actors might start to differentiate themselves through specialized tactics and goals. In addition, actors might formalize the resource linkages from the initial structure. As a result a social movement (or part thereof) might evolve more towards quadrants II or IV, or some point in between (keeping in mind that our framework is based on a continuum or multiple characteristics).

\section{Informal centralized structures}

Anheier (2003) describes how individual social movement entrepreneurs can play a major role in the growth of a social movement. In the case of the growth of the Nazi ideology in Germany between 1925 and 1930, he describes how a multitude of individuals, each of them strongly influenced by the central "body of thoughts," is deterministic in the rapid growth of a social movement. That is, individual movement entrepreneurs initiate events that are intertwined with people's everyday lives at the local political level. With respect to the growth of the Nazi-ideology in Germany, a broadly developed informal structure, centralized around a strong ideological source, resulted in the large electoral success of the "Nationalsozialistische Deutsche Arbeiterpartei" (NSDAP) (in 1930 and 1932). As Anheier notes: "This structure emphasized individual participation in numerous local events, meetings and quasi-military activities. The NSDAP as an organization was thus able to link the level of national and regional party politics to the everyday lives of party members and thereby managed to create a sense of community or 'Gemeinshaft'” (2003, p. 51). The movement structure described supports the creation of a "sense of community," building on individuals' participation in different events and organizations. Formalization of this structure after the electoral success, by incorporating the organizing committees of these initiatives within the party structure or requiring party membership of individuals to participate, means a switch from informal centralized structure (Quadrant IV) to formal centralized structure (Quadrant I).

Another ideology-based example, although in this case not resulting in a strongly formalized structure, is the Falun Gong movement in China at the end of the nineties as described by Thorthon (2002) and McDonald (2004). Falun Gong is a form of exercise typically practiced in public places by large groups of people. The synchronized nature of the movements shows a large sense of connection of the people involved. Growing numbers of people practiced Falun Gung in the late nineties at public places in China until it was forbidden in 1999. The ideas of Falun Gong founder Li Hongzhi are the central body of thought on which the structured exercises are based (Thorthon, 2002). Relations among practitioners are informal and it is easy to join since there are no formal requirements. McDonald (2004) stresses how the movement enhances sense of belonging among practitioners: "Sociological theory, in particular the tradition drawing on Durkheim, can easily interpret ritual and body practice in terms of production of belief and belonging, where forms of co-presence generate deindividuation, the dissolution of the subject into the collective" (p. 579). Furthermore, McDonald (2004) describes how forms of actions focus on 
this "deindividuation," rather than on representation. Forms of actions are mainly based on the collective participation in ideological activities. In general, descriptions of social movements in the literature often start from the assumption that a collective identity exists on which collective behavior is based. The case of Falun Gong presented by McDonald however, takes an opposite perspective, in that for this particular form of social movement (or part thereof), collective action leads to collective identity. We can therefore assume that both perspectives are mutually reinforcing (Polletta, 1999).

In general, we argue that an informal centralized movement structure typifies an (early) ideology-based movement. Participation and shared activities, based on a central body of thoughts, creates a sense of belonging and leads, as McDonald suggests, to "deindividuation." Through this structure collective identity is enforced, and as a result, the movement may formalize over time.

\section{DISCUSSION}

In the cases presented above, we focused on the relationship between, on the one hand, movement structure, and on the other, the goals and forms of action of social movements. We argue that different movement structures relate to different types of goals and tactics. Figure 2 gives an overview of characteristics of goals and forms of actions based on our generalized findings from the cases described above.

\section{Figure 2: Summarizing characteristics of goal and tactics based on underlying organizational structure}

\begin{tabular}{|c|c|c|}
\hline $\begin{array}{l}\text { I Goals: Maintain and incrementally } \\
\text { improve achievements } \\
\text { Tactics: (Political) bargaining based on a } \\
\text { large representation of grouped actors, by } \\
\text { use of 'portfolios of combined methods' } \\
\text { Cases: Contemporary (South-African / } \\
\text { USA) labor movement (Buhlungu, 2008; } \\
\text { Voss and Sherman, 2000) }\end{array}$ & $\begin{array}{c}\text { Formal } \\
\text { Structure }\end{array}$ & $\begin{array}{l}\text { II Goals: Differentiated and specialized } \\
\text { per actor in the network, within the context } \\
\text { of a general 'cause' } \\
\text { Tactics: Differentiated and specialized } \\
\text { tactics per actor in the network; different } \\
\text { fields of activism } \\
\text { Cases: Contemporary (USA) environmental } \\
\text { movement (Johnson, 2008; Hoffman, 2009); } \\
\text { Gay and lesbian movement - early seventies } \\
\text { (Armstrong, 2005) }\end{array}$ \\
\hline $\begin{array}{r}\text { Centralized } \\
\text { Structure }\end{array}$ & & $\rightarrow \begin{array}{l}\text { Clustered } \\
\text { Structure }\end{array}$ \\
\hline $\begin{array}{l}\text { IV Goals: Creating 'sense of community' } \\
\text { towards central ideas and/or ideology } \\
\text { Tactics: Participation and collective action } \\
\text { in diverse 'every-day-life' events initiated by } \\
\text { social movement entrepreneurs and/or } \\
\text { leaders } \\
\text { Cases: Growth of the Nazi-ideology in } \\
\text { Germany - } 1925 \text { till } 1930 \text { (Anheier; 2003); } \\
\text { Falun Gong movement in China - late } \\
\text { nineties (Thorthon, 2002; McDonald, 2004) }\end{array}$ & $\begin{array}{l}\text { Informal } \\
\text { Structure }\end{array}$ & $\begin{array}{l}\text { III Goals: Overall and abstract goals that } \\
\text { are straightforward to identify with based on } \\
\text { emergence of 'collective identity' } \\
\text { Tactics: Spontaneous and flexible activities } \\
\text { directed towards a broad base of supporters, } \\
\text { with no or little restrictive requirements to } \\
\text { join } \\
\text { Cases: Afro-American rights movement - } \\
\text { mid-fifties till the mid sixties (McAdam and } \\
\text { Scott, 2005); Feminist movement (Roth, } \\
\text { 2004; Taylor, 1989) }\end{array}$ \\
\hline
\end{tabular}

However, we must treat social movements as dynamic objects of study, as both internal and external factors might lead to changes in social movements' structures, goals, and tactics. Different evolutionary trends can be 
distinguished within and between the quadrants in the model. Informal and clustered structures at the base of a social movement grow as a result of the emergence of a collective identity among actors that favour similar highlevel, though rather abstract goals. The existence of many informal connections enables spontaneous and easy-tojoin forms of actions. The growth of a clustered network and collective identity mutually support one another (Quadrant III). When the organization has the support and legitimacy of a critical mass of actors: (1) more central nodes might come forward as leading actors, while (2) existing linkages might be formalized in alliances and partnerships to enhance the sustainability of actions and resources and to reduce uncertainty when exchanging specialized and complex knowledge. The emergence of central and leading nodes can be influential in shaping the content of goals and tactics of social movements (or parts thereof), and can enhance the sense of collectivity among actors. Forms of actions are often directed internally through individuals' participation in events, meetings, and activities (Quadrant IV). The formalization of linkages between actors, whether or not in combination with the emergence of central nodes, enables actors' differentiation towards more concrete goals and tactics within the larger "cause." Actors specialize in order to deal with more concrete aspects of the overall social movement, while the creation of formal alliances and partnerships reduces uncertainty on resource linkages (Quadrant II).

The distinction between an evolution from Quadrant III towards quadrants II or IV shows us two separate processes of social movements. In practice, however, these shifts might happen in parallel, regardless of whether one process is more dominant than the other. As an example, in their description of the US peace movement after the Cold War, between 1988 and 1992, Edwards and Marullo (1995) find the transition of peace organizations to more specialized niches, and there is also a tendency to group initiatives into nationwide collaborations (i.e., showing trends towards both quadrant II and IV).

A third evolution, starting from quadrant II, III or IV, is the combined formalization of relations and the centralization of actors in grouped initiatives, platforms, umbrella organizations, or political formations. This type of evolution supports the sustained and incremental improvement of overall achievements by using a large representation of people and/or organizations, resource base, and built-up capacity (Quadrant I). Depending on internal and external factors, such as new leadership strategies, political changes, or socio-demographic evolutions, social movements (or parts thereof) tend either to marginalize or revitalize (Buhlungu, 2008; Rodgers, 2010; Voss \& Sherman, 2000). When they become more marginalized, goals and/or tactics become less relevant or less supported by the base of the movement, while revitalization uses of an innovative and broader set of tactics to maintain and improve upon previous achievements.

\section{FUTURE CHALLENGES}

In this article, we propose a general classification framework for understanding the characteristics of social movements, linking movement structure with goals and forms of actions. We build upon a variety of cases from different movements at different moments to enhance the generalizability of this framework (Snow, Rochford, Worden \& Benford, 1986). In addition, we discuss the dynamic nature of structural characteristics, goals, and forms of action. For our explanation we use extensive and well-documented case studies and insights from seminal contributions to the literature. However, important avenues for further research are open.

First, more cases from the literature could be reviewed for an enhanced and more exhaustive explanation of the relationship between movement structure, goals, and forms of actions. Second, original data analyses for the purpose of scrutinizing this model are important. More detailed and directed analyses of structural aspects, goals, and tactics at certain moments in time for certain parts of social movement will enable a more thorough description of the relationship between the concepts studied. This exercise may even result in the falsification of the model presented here, which is ultimately beneficial in that it will lead to the framework's continued adaptation or revision. 
The process of adaptation and revision will enhance academic insight into the structural aspects of social movements related to goals and forms of action. Third, in the description given above we left out a detailed analysis of the potential factors, internal or external, that might be at the origin of different structural characteristics, or which may cause the shift between different quadrants in the model (Benford \& Snow, 2000). In future research, incorporating exogenous and contextual factors, and/or internal dynamics, could also enhance the relevance of the model for its further application to the structure of social movements.

\section{ACKNOWLEDGEMENTS}

The authors thank Guy Vanthemsche (Vrije Universiteit Brussel) for his valuable feedback and support while developing this article.

\section{REFERENCES / BIBLIOGRAPHIE}

Anheier, H. (2003). Movement development and organizational networks: The role of 'single members' in the German Nazi Party, 1925-30. In D. Mario \& M. Dough (Eds.) Social movements and networks: Relational approaches to collective action (pp. 49-76). Oxford, UK: Oxford University Press.

Armstrong, E.A. (2005). From struggle to settlement: The crystallization of a field of lesbian/gay organizations in San Francisco, 1969-1973. In G.F. Davis, D. McAdam, W.R. Scott \& M.N. Zald (Eds.) Social Movements and Organization Theory (pp. 161-188). New York: Cambridge University Press.

Arya, B., \& Lin, Z. (2007). Understanding collaboration outcomes from an extended resource-based view perspective: The roles of organizational characteristics, partner attributes, and network structures. Journal of Management, 33(5), 697-723.

Bakuniak, G., \& Nowak, K. (1987). The creation of a collective identity in a social movement: The case of "Solidarnośc" in Poland. Theory and Society, 16(3), 401-429.

Bayat, A. (1997). Un-civil Society: the politics of the 'informal people'. Third World Quarterly, 18(1), 53-72.

Benford, R.D. (1997). An insider's critique of the social movement framing perspective. Sociological Inquiry, 67(4), 409-430.

Benford, R.D., \& Snow, D.A. (2000). Framing processes and social movements: An overview and assessment. Annual Review of Sociology, 26, 611-639.

Buhlungu, S. (2008). Gaining influence but losing power? COSATU members and the democratic transformation of South Africa. Social Movement Studies, 7(1), 31-42.

Burstein, P., \& Linton, A. (2002). The impact of political parties, interest groups, and social movement organizations on public policy: Some recent evidence and theoretical concerns. Social Forces, 81(2), 381-408.

Burt, R. (2004). Structural holes and good ideas. American Journal of Sociology, 110(2), 349-399.

Child, J., \& Francis, A. (1976). Strategy formulation as a structured process. University of Ashton in Birmingham Management Centre Working Paper Series, No. 59.

Coase, R.H. (1937). The nature of the firm. Economica, 4(16), 386-405.

Coleman, J.S. (1988). Social capital in the creation of human capital. American Journal of Sociology, 94, 95-120.

Das, T.K., \& Teng, B.S. (2000). A resource-based theory of strategic alliances. Journal of Management, 26(1), 31-61.

Den Hond, F., \& De Bakker, F.G. (2007). Ideologically motivated activism: How activist groups influence corporate social change activities. Academy of Management Review, 32(3), 901-924.

DiMaggio, P. (2001). Measuring the impact of the nonprofit sector on society is probably impossible but possibly useful: A sociological perspective. In P. Flynn, \& V. A. Hodgkinson, (Eds.), Measuring the impact of the nonprofit sector (pp. 249-272). New York: Kluwer Academic/Plenum Publishers. 
Eden, C., \& Huxham, C. (2001). The negotiation of purpose in multi-organizational collaborative groups. Journal of Management Studies, 38(3), 373-391.

Edwards, B., \& Marullo, S. (1995). Organizational mortality in a declining social movement: The demise of peace movement organizations in the end of the cold war era. American Sociological Review, 60(6), 908-927.

Galaskiewicz, J. (1985). Interorganizational relations. Annual Review of Sociology, 11, 281-304.

Galbraith, J.R. (1971). Matrix organization designs: How to combine functional and project forms. Business Horizons, 14(1), 29-40.

Granovetter, M.S. (1973). The strength of weak ties. American Journal of Sociology, 78(6), 1360-1380.

Hansen, M.T. (1999). The search-transfer problem: The role of weak ties in sharing knowledge across organization subunits. Administrative Science Quarterly, 44(1), 82-111.

Hargrave, T., \& Van de Ven, A.H. (2006). A collective action model of institutional innovation. Academy of Management Review, 31(4), 864-888.

Hensmans, M. (2003). Social movement organizations: A metaphor for strategic actors in institutional fields. Organization Studies, 24(3), 355-381.

Hoffman, A.J. (2009, Spring). Shades of green. Stanford Social Innovation Review.

Jenkins, J.C., \& Eckert, C.M. (1986). Channeling black insurgency: Elite patronage and professional social movement organizations in the development of the black movement. American Sociological Review, 51(6), 812-829.

Johnson, E.W. (2008). Social movement size, organizational diversity and the making of federal law. Social Forces, 86(3), 967-993.

Kriesi, H. (1996). The organizational structure of new social movements in a political context. In D. McAdam, J.D. McCarthy \& M.N. Zald (Eds.) Comparative perspectives on social movements: Political opportunities, mobilizing structures, and cultural framings (pp. 152-184). New York: Cambridge University Press.

Kukalis, S. (1991). Determinants of strategic planning systems in large organizations: A contingency approach. Journal of Management Studies, 28(2), 143-160.

Lawrence, P.R., \& Lorsch, J.W. (1967). Differentiation and integration in complex organizations. Administrative Science Quarterly, 12(1), 1-47.

Leflaive, X. (1996). Organizations as structures of domination. Organization Studies, 17(1), $23-47$.

McAdam, D., \& Scott, R.W. (2005). Organizations and movements. In G. F. Davis, D. McAdam, W. R. Scott, \& M.N. Zald (Eds.) Social movements and organization theory (pp. 4-40). New York: Cambridge University Press.

McCarthy, J. D., \& Wolfson, M. (1996). Resource mobilization by local social movement organizations: Agency, strategy, and organization in the movement against drinking and driving. American Sociological Review, 61(6), 1070-1088.

McCarthy, J. D. \& Zald, M.N. (1977a). The trend of social movements in America: Professionalization and resource mobilization. CRSO Working Paper, No. 164.

McCarthy, J.D., \& Zald, M.N. (1977b). Resource mobilization and social movements: A partial theory. American Journal of Sociology, 82(6), 1212-1241.

McDonald, K. (2004). Oneself as another: From social movement to experience movement. Current Sociology, 52(4), 575-593.

Obstfeld, D. (2005). Social networks, the tertius iungens orientation, and involvement in innovation. Administrative Science Quarterly, 50(1), 100-130.

Polleta, F. (1999). "Free spaces" in collective action. Theory and Society, 28(1), 1-38.

Provan, K.G., \& Milward, H.B. (2002). Do networks really work? A framework for evaluating public-sector organizational networks. Public Administration Review, 61(4), 414-423.

Robertson, P.J., \& Tang, S. (1995). The role of commitment in collective action: Comparing the organizational behavior and rational choice perspectives. Public Administration Review, 55(1), 67-80.

Rodgers, K. (2010). "Anger is why we're all here": Mobilizing and managing emotions in a professional activist organization. Social Movement Studies, 9(3), 273-291. 
Roelofs, J. (2009). Networks and democracy: It ain't necessarily so. American Behavioral Scientist, 52(7), 990-1005.

Rojas, F. (2006). Social movement tactics, organizational change and the spread of African-American studies. Social Forces, 84(4), 2147-2166.

Roth, B. (2004). Thinking about challenges to feminist activism in extra-feminist settings. Social Movement Studies, $3(2), 147-166$.

Ruef, M. (2000). The emergence of organizational forms: A community ecology approach. Journal of Sociology, 106(3), 658-714.

Schneiberg, M., King, M., \& Smith, T. (2008). Social movements and organizational form: Cooperative alternatives to corporations in the American insurance, dairy, and grain industries. American Sociological Review, 73(4), 635667.

Selsky, J.W., \& Parker, B. (2005). Cross-sector partnerships to address social issues: Challenges to theory and practice. Journal of Management, 31(6), 849-873.

Shumate, M., Fulk, J., \& Monge, P. (2006). Predictors of the international HIV-AIDS INGO network over time. Human Communication Research, 31(4), 482-510.

Simon, B., Loewy, M., Stürmer, S., Weber, U., Freytag, P., Habig, C., Kampmeier, C., \& Spahlinger, P. (1998). Collective identification and social movement participation. Journal of Personality and Social Psychology, 74(3), 646-658.

Snow, D.A., Zurcher Jr., L.A., \& Ekland-Olson, S. (1980). Social networks and social movements: A microstructural approach to differential recruitment. American Sociological Review, 45(5), 787-801.

Snow, D.A., Rochford Jr,, E.B., Worden, S.K., \& Benford, R.D. (1986). Frame alignment processes, micromobilization, and movement participation. American Sociological Review, 51(4), 464-481.

Suchman, M.C. (1995). Managing legitimacy: Strategic and institutional approaches. Academy of Management Review, 20(3), 571-610.

Tarrow, S. (1994). Power in movement: social movements, collective action and politics. New York: Cambridge University Press.

Taylor, J. (2007). Organizational elaboration as social movement tactic: A case study of strategic leadership in the first US school-sponsored program for gay and lesbian youth. Social Movement Studies, 6(3), 311-326.

Taylor, M., \& Doerfel, M.L. (2011). Evolving network roles in international aid efforts: Evidence from Croatia's post war transition. Voluntas: International Journal of Voluntary and Nonprofit Organizations, 22(2), 311-334.

Taylor, V. (1989). Movement continuity: The women's movement in abeyance. American Sociological Review, 54(5), 761-775.

Thornton, P.M. (2002). Framing dissent in contemporary China: Irony, ambiguity and metonymy. The China Quarterly, 171(1), 661-681.

Uzzi, B. \& Lancaster, R. (2003). Relational embeddedness and learning: The case of bank loan managers and their clients. Management Science, 49(4), 383-399.

Voss, K., \& Sherman, R. (2000). Breaking the iron law of oligarchy: Union revitalization in the American labor movement. American Journal of Sociology, 106(2), 303-349.

Williamson, O.E. (1967). Hierarchical control and optimum firm size. Journal of Political Economy, 75(2), 123-138.

Williamson, O.E. 1991. Comparative economic organization: The analysis of discrete structural alternatives. Administrative Science Quarterly, 36(2), 269-296.

Zald, M.N., \& Ash, R. (1966). Social movement organizations: Growth, decay and change. Social Forces, 44(3), 327-341.

\section{ABOUT THE AUTHORS / LES AUTEURS}

Jurgen Willems is a Post-Doctoral researcher at the Vrije Universiteit Brussel (Free University Brussels). Email: jurgen.willems@vub.ac.be

Marc Jegers is a Professor at the Vrije Universiteit Brussel. Email: marc.jegers@vub.ca.be 